\title{
RELACIONES PÚBLICAS: IBERISMO Y PROSPECTIVA
}

\section{PUBLIC RELATIONS. IBERIANISM AND PROSPECTIVE}

David Caldevilla Domínguez: Profesor del Área de Comunicación en la Universidad Complutense de Madrid, la Universidad Europea de Madrid y Escuela Superior de Estudios de Relaciones Públicas david.caldevilla@ccinf.ucm.es

\section{CURRÍCULUM VITAE}

Diplomado en Magisterio por la Universidad de Zaragoza (España), licenciado en Comunicación Audiovisual por la Universidad Complutense de Madrid (España). Profesor en la Facultad de Ciencias de la Información de la Universidad Complutense. Secretario General del Fórum Internacional de Comunicación y Relaciones Públicas (España) y autor de varios artículos en revistas universitarias. Director de Operaciones de Imagométrica, s.l. y ex directivo de varias firmas españolas del ámbito de la mercadotecnia.

\section{RESUMEN}

La prospectiva es nuestro cuerpo óptico enfocador de la realidad circundante de hoy para entender nuestras acciones cuyos resultados veremos mañana. La prospectiva surge del ámbito empresarial, el más dado a la seguridad y el menos cercano a la teoría. Las herramientas de que disponemos en anticipación son variadas. La más empleada es el llamado método Delphi, que sirve para obtener una previsión de futuro cuantificada por consenso sobre temas cualitativos a fin de ayudar en la toma de decisiones. El ser humano se mueve por: Interés, Necesidad y Prejuicio. Sólo éste 
último factor se escapa al control inmediato del raciocinio. Uno de los ejemplos más claros de aplicación de la prospectiva en temas políticos pueda ser el eterno conflicto árabe-israelí ya desde tiempos de la descolonización británica de aquellas tierras tras la II Guerra Mundial. El actual Modelo UR 2000, llevado a cabo en el ámbito de la educación universitaria en México, es en realidad el importante resultado de la aplicación del Estudio de los Futuros, ya que la idea era mejorar paulatinamente en un plan continuado y nada rupturante hasta tan emblemática fecha, sentando las bases, de entre todos los futuros posibles, del más preferible para la educación universitaria. La prospectiva inversa es la herramienta que sirve para preparar el futuro según los intereses que consideremos éticamente más adecuados para una persona, una ciudad, una organización o un país, por proponer aplicaciones cercanas. El ejemplo más claro al respecto fue la promesa del presidente estadounidense J. F. Kennedy de que el hombre llegaría a la luna antes de 1970. Esto también tiene su relación con las Relaciones Públicas.

\section{PALABRAS CLAVE}

Prospectiva - Futuro - Previsión - Relaciones Públicas - Modelo UR 2000 - II ${ }^{\mathrm{a}}$ Guerra Mundial

\section{ABSTRACT}

Foresight is our optical focuser body surrounding reality of today to understand our actions whose results we will see tomorrow. Foresight comes from business, given the more security and less close to theory. The tools we have in advance are varied. The most commonly used is called the Delphi method, used to obtain a forecast of future quantified by consensus on qualitative issues to assist in decision-making. The human being moves: Interest, Need and Prejudice. Just this last factor is beyond the immediate control of reason. One of the clearest examples of application of foresight 
in political issues may be the eternal Arab-Israeli conflict since the time of the British colonization of those lands after World War II. The current Model UR 2000, carried out in the field of university education in Mexico is actually the important result of the implementation of the Future Study, since the idea was to improve gradually in a continuing plan and nothing rupturante to as emblematic date, laying the foundation, of all possible futures, the most preferable for higher education. The prospective reverse is the tool used to prepare the future as the interests we consider ethically appropriate for a person, a city, an organization or a country, to propose nearby applications. The clearest example in this regard was the promise of U.S. President J. F. Kennedy that man would reach the moon before 1970. This too has its relationship with public relations.

\section{KEY WORDS}

Prospective - Future - Welfare - Public Relations - UR Model 2000 - World War II

\section{ÍNDICE}

1. Declaración de principios

2. ¿Qué es la prospectiva?

3. La prospectiva aplicada

3.1 Guerra Árabe-Israelí

3.2 Un ejemplo para la educación superior

3.3 Iberismo

4. La prospectiva inversa

5. Planes proiberistas y campañas de Relaciones Públicas

6. Glosario

7. Bibliografía

8. Webgrafía y correles de interés 


\section{TEXTO}

\section{Declaración de principios}

Mucho se ha hablado sobre lo que es el iberismo y lo que supone hoy en día, con separatismos intramuros y grandes uniones continentales. Incluso en una ucronía se ha planteado más de una vez qué hubiera sido del mundo y de la península ibérica en particular, si estos dos reinos surgidos uno en la Edad Media (1139-1580 y 1640hoy) y en la Edad Moderna en el caso del otro (1512-hoy), hubieran estado unidos en su conquista oceánica.

Hoy surgen voces muy autorizadas que preconizan la unión de los que hoy son dos y durante muchos siglos no fueron sino uno para romanos, godos, musulmanes e inicios de la Reconquista.

Desde los siglos de oro de la literatura española, XVI y XVII, se ha considerado a Camões, quien fuera amigo de Lope de Vega y detractor de Luis de Góngora como un poeta luso, pero lo que es menos conocido y sin embargo más importante, se le ha coronado como Príncipe de los Poetas de España. Esta simple idea de fusión puede ser considerada como de vasallaje o invasión cultural de un país en otro. Nada más lejos de la realidad aunque pueda sonar muy creíble.

Lo verosímil se impone una vez más a lo veraz.

El folclorismo, localismo e incluso el patrioterismo son muy buenos desayunos pero muy malas cenas. La responsabilidad social de algunos líderes de opinión habría de estar más influida por el bien común, aunque conlleve sacrificios, que en el placer momentáneo que hace ganar elecciones gracias a la demagogia, ya inventada en el siglo IV antes de Cristo por el ateniense Demóstenes 3, pero que hace naufragar a los pueblos más allá de la inicial navegación de cabotaje.Si desde hace siglos se ha 
pretendido desunir a los pueblos gracias a la ingente labor publirrelacionista de los separatistas y de los separadores, es hora de preguntarse ¿Quién ha creado en nosotros estas ideas?. Se podría argüir que definen la verdadera realidad actual y pretérita circundante, pero éste es sólo un análisis practicado a un desechable nivel epidérmico, el cual, desde la Universidad (Unus versus alia, en su etimo, es decir, lo que de uno va hacia lo plural) ha de ser desmontado en su radical falsedad.

Es irónico ver que, con harta frecuencia, quienes abogan por una desmembración de pueblos en unos foros, considerando una cultura cercana como invasora, un idioma común como opresor, defienden superlativamente en otros la unión bajo el techo común de la bandera de las quince estrellas amarillas y una lingua franca ajenísima a su entorno de desarrollo cultural como koiné. Nuestro prójimo es nuestro próximo. ¿Quién ha salido beneficiado con esta situación?...

Desde el vasto campo de las Relaciones Públicas, a veces, los profesionales tanto de su docencia como de su aplicación mercantil, nos vemos abocados a plantearnos unas preguntas fundamentales en ambos campos:

¿Qué repercusiones tendrán en el futuro nuestras acciones de hoy?, ¿Somos las personas adecuadas para transmitir valores perennes?, ¿Qué ideas merecen perdurar?. Si el presente era el futuro del pasado... ¿Quiénes diseñaron nuestro hoy, es decir, nuestra realidad, valores e ideas actuales?.

Si el periodismo nos ha enseñado, gracias a Rudyard Kipling, que tiene cinco grandes amigos (las famosas Ws sajonas):

\section{Quién}

Cómo

Cuándo 
Dónde

Por qué

que no suponen más que un remedo de las $7 \mathrm{Q}$ del calagurritano Marco Fabio Quintiliano (39-95)

Quis (quién)

Quid (qué)

Ubi (dónde)

Quibus auxiliis (con qué)

Cur (por qué)

Quomodo (cómo)

Quando (cuándo)

las Relaciones Públicas nos plantean sólo dos, pero mucho más clarificadoras que sus antecesoras en el cetro del interés:

\section{Para qué}

Quién sufraga esto ( o lo que es lo mismo, quién sale ganando con esto)

Este pragmatismo poco romántico ha de ser entendido enmarcado en la praxis propia de la comunicación persuasiva, es decir, la que está más enfocada a la obtención de resultados. Su validez caminaría pareja de sus logros.

La Escuela Española de Relaciones Públicas a cuya cabeza se encuentra el primer catedrático de la materia que ha habido en España y profesor emérito de la Facultad de Ciencias de la Información de la Universidad Complutense de Madrid, Dr. D. Luis Solano Fleta 4, en cambio, plantea otra visión a la que me adhiero pero que deseo matizar para algunas situaciones. Dicha Escuela de pensamiento e investigación ha 
centrado su corpus teórico a partir de la identificación primigenia, atribuida al padre del Publirrelacionismo, el periodista estadounidense Ivy Ledbetter Lee, de las Relaciones Públicas como agentes de información veraz que no de persuasión, mediante la cual es más sencillo obtener la simpatía de los públicos a los que va enfocada, cuyo objeto final es. Su validez caminaría pareja de su veracidad.

Las Relaciones Públicas son ciencia teleológica, pues su causa está planteada tras sus efectos y éstos, como afirmara el prolijo autor y profesional de la comunicación empresarial persuasiva Philip Lesly en su Manual de Relaciones Públicas (Ed. Martínez Roca. Barcelona, 1969) del ahora lejano año 1969, pero cuyos vívidos contenidos son perfectamente aplicables a nuestros trabajos de prospectiva: "Así como la ciencia nos da un mayor control sobre la materia, las máquinas y los métodos, debemos aprender a controlar a la gente con una creciente efectividad. Las Relaciones Públicas, como un medio de intercambiar y conformar actitudes, pueden en gran manera acelerar las adaptaciones sociales requeridas por nuestro progreso material sin necesidad de moldear la opinión pública dentro de unos rígidos estilos totalitarios."

Muy en línea de lo anterior Bertrand R. Canfield en su libro Relaciones Públicas (Ed. Mundi. Buenos Aires, 1978) redunda la vía de la creación de Opiniones Públicas muy importante para la prospectiva inversa, como veremos: “Como el principal objetivo de las Relaciones Públicas es influir sobre la Opinión Pública, es igualmente importante comprender la naturaleza de la opinión de un grupo y de qué manera puede ser moldeada la misma para desarrollar la buena voluntad del público" y añade sin rubor "el objetivo esencial de las Relaciones Públicas es el de moldear la Opinión Pública e influir sobre ella". Sin duda es un apoyo a la afirmación de Scott M. Cutlip y Allen H. Center en su libro Relaciones Públicas (Ed. Rialp. Madrid 1963) de que "el propósito común de todo lo que se denomine Relaciones Públicas es el de influir en la Opinión Pública". 
Si modelizamos el paradigma de Harold Laswell 5 (quién dice qué a quién por qué canal con qué efecto), resultaría que la retroalimentación del sistema es el eje central de nuestro trabajo.

Nota: (La codificación / descodificación se presupone siempre correcta, es decir, no aberrante)

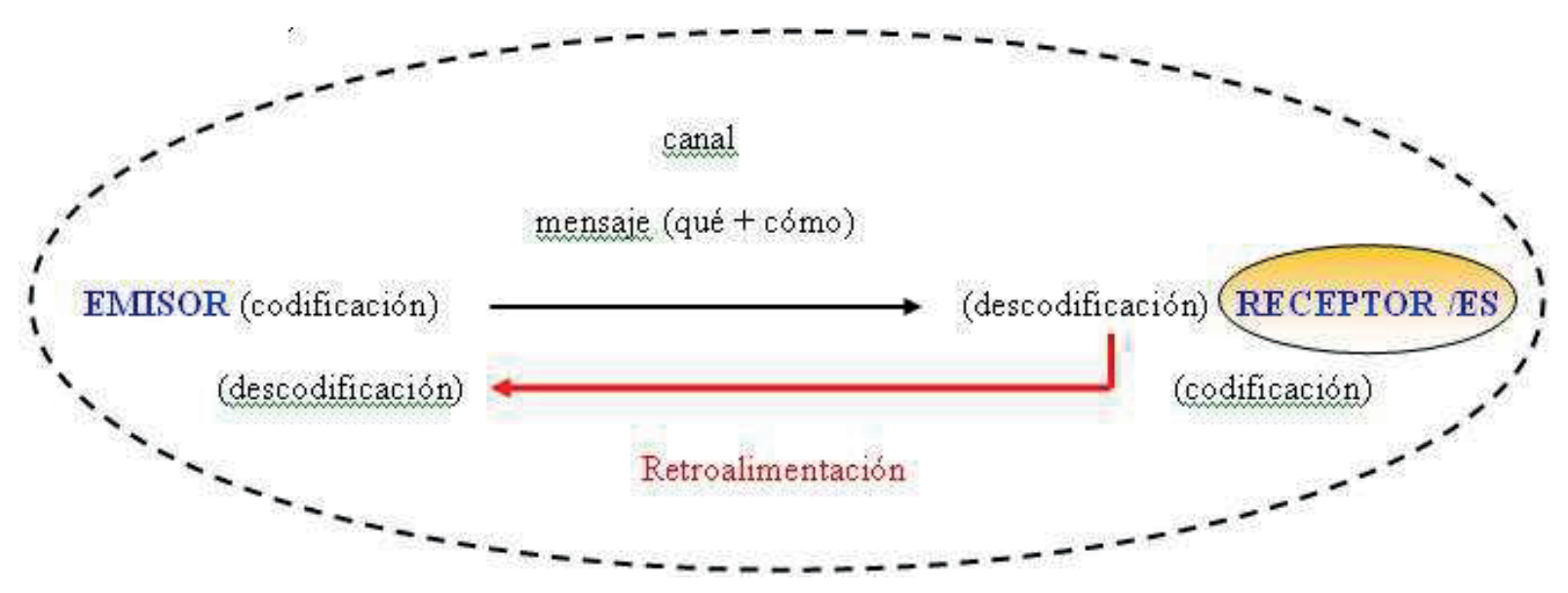

ÁREA DE LA OPINIÓN PÚBLICA por adición de Receptores agrupados ya sea por propia voluntad y consentimiento (ejemplo: un partido político, un equipo deportivo...), como por "etiquetado" desde el Emisor sin voluntad ni conciencia de pertenencia (ejemplo: Las audiencias de un programa de TV, el hecho de calzar una talla 42 de zapatos...).

1- Harold Macmillan: (1894-1986). Primer ministro británico entre 1957 y 1963. En 1924 elegido diputado por el Partido Conservador. Desde la II Guerra Mundial ocupó diversos cargos en el gobierno del primer ministro Winston Churchill, entre los que se cuentan el de ministro de Suministros (1940-1942) y el de subsecretario de Estado para las Colonias (1942), ministro de la Vivienda (1951-1954), ministro de 
Defensa (1954-1955), ministro de Asuntos Exteriores (1955) y ministro de Hacienda, (1955-1957). En 1957 ocupó la presidencia de gobierno. Partidario de negociaciones Este-Oeste, visitó al primer ministro soviético Nikita S. Jruschov en Moscú en 1959.

2- Alfred North Whitehead: (1861-1947) Filósofo británico. La influencia filosófica de Whitehead se puede sentir en tres de las áreas principales en las que trabajó: lógica y las fundaciones de las matemáticas, de la filosofía de la ciencia, y de la metafísica; así como en otras áreas tales como éticas, educación y religión. Whitehead comenzó su carrera académica en la universidad de Cambridge (Gran Bretaña), en donde, comenzando en 1885, él enseñó por veinticinco años. Fue profesor de Bertrand Russell con quien colaboraría más tarde en sus Principia Mathematica (1910, 1912, 1913). Whitehead viajó a Harvard (Estados Unidos) en 1924.

3- Demóstenes: (c. 385-322 a.C.) Político ateniense, el orador más grande de la antigua Grecia, dirigió la oposición de Atenas frente a Macedonia. Centró su actividad en escribir discursos que usó en litigios legales particulares. Según sus biógrafos sufría un impedimento del habla y sus intentos de expresar sus propios discursos fueron tan infructuosos que recurrió a medios poco frecuentes para superar su defecto, incluida la práctica de hablar con guijarros en la boca. Aunque Demóstenes continuó la práctica legal privada, se interesó cada vez más por los asuntos públicos. Se dedicó a restablecer el espíritu público en Atenas y a la conservación de la cultura griega. La mayoría de sus principales discursos estuvieron dirigidos contra el poder creciente del rey Filipo II de Macedonia (padre del Futuro Alejandro III el Magno), a quien veía como una amenaza no sólo para Atenas sino para todas las ciudades-estado griegas. El tema principal de su primer discurso contra Filipo, conocido como la Primera Filípica (351 a.C.) de las tres que compondría, fue todo un presagio, ya que dos años más tarde Filipo atacó Olinto, aliado de Atenas, y en tres discursos, llamados las Olínticas, Demóstenes exhortó a Atenas a ayudar a su aliado. Cuando Olinto fue destruido, Demóstenes estaba entre los enviados (346 a.C.) para negociar 
la paz entre Atenas y Filipo. Antípatro, sucesor de Alejandro Magno y heredero de los territorios griegos que conquistó Filipo II tras Queronea, sofocó toda resistencia ateniense y exigió que le entregaran a Demóstenes y a otros líderes patriotas. Cuando la asamblea ateniense aprobó una sentencia condenando a muerte a los patriotas, Demóstenes huyó a un santuario en la isla de Calauria, donde se suicidó. La fama de sus discursos continuó durante siglos, inspirando al orador romano Cicerón, entre otros, en sus discursos contra Marco Antonio después de la muerte de Julio César.

4- El Prof. Dr. Luis Solano Fleta es autor de numerosos libros de Relaciones Públicas, en los que es destacable su contribución al estudio epistemológico en el campo formal, estructural, histórico y práctico del fenómeno Publirrelcionista. Basa su pensamiento, plasmado en su labor docente e investigadora desde hace más de 30 años, en el concepto científico de los saberes denominados del hombre, del espíritu o humanidades (por oposición a los de la materia) para aplicar los resultados a las Relaciones Públicas y eliminar el adhoquismo inútil propio de un empirismo desteorizado. Director de Fórum Internacional de Comunicación y Relaciones Públicas, es la cabeza visible de la Escuela Española. Dedica actualmente sus esfuerzos investigadores al concepto de responsabilidad social corporativa. Asimismo es director del Departamento de Comunicación Audiovisual y Publicidad II (CAVP II) de la Facultad de CC.II. de la Universidad Complutense.

5- Harold Laswell: Cientifista y político estadounidense. Entre 1940 y 1945 trabajó en la Biblioteca del Congreso de los Estados Unidos, como jefe de la División Experimental para el Estudio de las Comunicaciones en Tiempo de Guerra. De 1946 a 1970, trabajó en la Universidad de Yale. Su interés por la propaganda política lo llevó a preocuparse por los fenómenos de la comunicación. Fue uno de los más influyentes activistas de la necesidad de desarrollar investigación en materia de comunicación y cumplió un papel importante en poner en marcha la institucionalización de esos estudios. Por ello se le identifica como uno de los padres fundadores de la 
investigación en el área. Formuló el conocido e influyente Modelo de las 5 preguntas: ¿Quién, dice qué, a quien, por qué canal, y con qué efecto? Aunque este modelo da por sentado el hecho de los efectos de los medios de comunicación, y aunque se asocia su nombre a una concepción de efectos poderosos de los medios, en verdad sus escritos evolucionaron hasta admitir la importancia de las predisposiciones y de las singularidades culturales en la recepción de los mensajes. Otro rasgo de su obra fue la aplicación de los conceptos del psicoanalista Sigmund Freud.

\section{2. ¿Qué es la prospectiva?}

La prospectiva sería por lo tanto nuestro cuerpo óptico enfocador de la realidad circundante de hoy para entender nuestras acciones cuyos resultados veremos mañana.

La prospectiva surge como necesidad de objetivizar las estrategias y tácticas entendidas como:

los pasos dados

los pasos que se dan

los pasos por dar

Si queremos saber cuál es el camino que se abre ante nuestros pies hemos de recurrir a echar la vista atrás para conocer nuestro origen, y, como prolongación racional, diseñar y designar nuestro porvenir cercano en un continuum lógico. La prospectiva pretende adelantar y adelantarse en el campo de ciertos aspectos menos claros, pero muy decisivos las más de las veces a las ecuaciones en que se escribe el futuro y comprende aquellos que moldean y modelan el presente y fueron escritos en las arcanas "tablas de arcilla" de nuestros mayores. 
Quizá el profesor Mitchell Feigenbaum y su teoría del caos 6 hayan supuesto el mayor avance matemático aplicable a las Relaciones Públicas, a la par que la aplicación estadística como conversora de magnitudes intensivas (gusto, filia, fobia, amor, odio, preferencias, rechazos...) en extensivas o mesurables (tantos por ciento, modas, medianas...). El primer intento de crear una ratio intensiva/extensiva en los fenómenos sociales y su predecibilidad fue la teoría de catástrofes 7, muy en boga en la década de los 70, de manera que incluso una corriente estético-temática del cine de aquellos años se centró en las "catástrofes" predecibles pero irremediables debido a la condición humana de falta de previsión porque "Todo está escrito".

La misma palabra futuro, en su etimología es el participio de futuro (futurus, futura, futurum) del verbo ser, algo así como "el que, la que o lo que ha de ser", frente a alea (o azar) o augurium (futuro predecible).

Sin pretender entrar en la eterna discusión entre los Nóbeles Albert Einstein y Niels Bohr sobre si Dios juega o no a los dados e incluso, como apostillaría el profesor Stephen Hawking si esconde la tirada, es cierto que estamos rodeados de fenómenos invariantes ante circunstancias similares, a lo que comúnmente damos en llamar ciencia, aunque nos cueste a veces encontrarlos. ¿Cómo aplicar ese rigor metodológico que procura resultados fiables, repetibles, exactos $\mathrm{y}$, por qué no decirlo, muy vendibles por su oropel y pátina cientifista a la sociología?. Es decir ¿Las ciencias del espíritu, humanistas se equipararán algún día a las de la naturaleza o materiales?. Este es el camino que propongo andar.

Hagamos un poco de historia: Durante mucho tiempo la predicción del futuro se ha encontrado denostada ya desde los orígenes de los mitos y epopeyas clásicas. Bajo el síndrome de Casandra 8 se han ocultado muchos de estos aspectos negativos, e incluso, se ha jugado en el cine con este concepto de premoniciones, como nos muestra la película "Doce Monos" (1996) de Terry Gilliam ya que uno de los rasgos 
de locura que le atribuyen al protagonista y por el que es internado en un psiquiátrico es precisamente éste: Cree que puede predecir el futuro.

Podemos definir la prospectiva inicialmente a partir de lo que no es y para lo que no sirve:

"El futuro" no puede ser "estudiado" porque "el futuro" no existe.

Ante esta orfandad manifiesta hemos de recurrir a analizar previamente qué es y para qué sirve la prospectiva y por ende qué no es y para qué no sirve.

Existen dos modelos básicos de entender el futuro:

Como proyección del pasado, de manera lógica y previsible aplicando la más pura lógica. El futuro parece entonces poco menos que irreversible. Recordemos la celebérrima frase de José Ortega y Gasset: Yo soy yo y mis circunstancias y si no las salvo a ellas, no me salvo yo, en clara alusión a la cita inmortal de Heródoto 9. Las circunstancias mueven al hombre, el hombre no mueve a las circunstancias.

Como elementos que pueden surgir en un tiempo delante del presente y platean diversas opciones lógicas que poseen mayor o menor grado de posibilidad de materialización. Recordamos la segunda parte de la frase de Ortega: ...Y si no hago nada por cambiarlas (las circunstancias) nunca cambiaré yo.

Esta segunda visión ayudará a entender lo que vamos a exponer a partir de la búsqueda que deseamos desarrollar.

Si buscamos:

Lo desconocido (futuro o no); recalaremos en un vidente que posea clarividencia que es la facultad paranormal de adivinar hechos futuros $u$ ocurridos en otros lugares. 
Una visión o conocimiento claro e inmediato, sin raciocinio; por lo que recurriremos a un visionario que cree que las cosas reales son inventadas o fantasiosas.

Una profecía o predicción de naturaleza sobrenatural; para lo que habrá que buscar un vidente-profeta quien sabe interpretar las señales emitidas por algo o alguien que quiere que su voluntad o designios sean conocidos. Se predicen cosas distantes o futuras en virtud de la profecía o revelación.

Anticipación o adelantamiento de sucesos a su previsible desarrollo; trataremos con expertos en ciencia-ficción o anticipadores que produzcan efectos inminentes sobre causas sabidas.

Futuro, es decir, lo que está por venir; propio de los futuristas o partidarios del futurismo quienes adoptan una actitud espiritual o política enfocada hacia metas futuras.

Prospección debida a los prospectivistas quienes realizan un conjunto de análisis y estudios a fin de explorar o predecir el futuro en algún campo o materia.

Futuro propio de los futurólogos, así llamados por practicar la futurología o conjunto de estudios que se proponen predecir científicamente el futuro del hombre. Se englobarían las dos categorías anteriores y habríamos hallado la senda de la prospectiva y de los prospectivistas.

La prospectiva surge del ámbito empresarial, el más dado a la seguridad y el menos cercano a la teoría. Durante el siglo XX se habían producido numerosas situaciones que escapaban al control de los observadores más puntillistas. El entorno tecnológico, económico, político y social en el que se desenvolvía el quehacer diario de las organizaciones empresariales mutaba como el virus de la gripe: de manera cuasi-aleatoria y cuyo origen era prácticamente desconocido. $\mathrm{O}$ al menos así se presentaba. La gestión estratégica del cambio, verdadero epicentro del trabajo de los mercadotecnas de todos los tiempos, comenzaba a resquebrajarse aún sin haber comenzado a planificar sus cimientos. Se precisaba una herramienta de centrado para 
que el trabajo en la gestión organizacional pudiera ver sus frutos incluso sobre el papel antes de tomar millonarias decisiones.

El diseño de estrategias, tanto en el ámbito político de la Administración Pública como en el de las organizaciones con ánimo de lucro conlleva la elección de una línea de actuación futura, previendo una serie de contextos probables. La estadística oferta aquí una vasta gama de posibilidades de aplicación, pero todos ellos parten de una base incuestionable o axioma: hay una visión determinista en los sucesos, aunque incognoscible de antemano. En lenguaje cotidiano: sabemos dónde queremos llegar (línea de actuación) pero ésta esta flanqueada por una serie de factores muy numerosos ajenos a nuestro control y lo que es peor, a nuestro conocimiento. Nada hay más fácil de acertar ni nos parece más lógico que una quiniela deportiva al día siguiente de haberse celebrado los encuentros. Y he aquí el abuso del lenguaje que nos lleva a la justificación de la prospectiva: Lo imprevisible no es impredecible.

Decía Sherlock Holmes que cualquier solución que se nos ocurriera para resolver un caso por extremadamente difícil o inverosímil que ésta fuera, descartadas las imposibles, era la verdadera. Sir Arthur Conan Doyle acertaba.

Las herramientas de que disponemos en anticipación son variadas. Recordemos algunas de las principales:

\section{Cuantitativas}

Análisis exploratorio frente a análisis causal

Análisis de series temporales o exploratorio

Análisis de regresión

Simple

Autocorrelación

Cualitativas 
Análisis exploratorio

Escenarios

Delphi

Matriz de impactos cruzados (MIC)

Análisis normativo

Árboles de decisión

Árboles de relevancia o método pattern

Dinámica de sistemas

Teoría de catástrofes

Varios

Analogía histórica

Análisis morfológico

Futuro proyectivo (Incasting)

Camino retrospectivo (Backasting)

Visioning

Futures work shop

El más empleado, que no único, es el llamado método Delphi que fuera inventado por la división de Investigación y Desarrollo de la Rank Corporation en los años 50. Sirve para obtener una previsión de futuro cuantificada por consenso sobre temas cualitativos a fin de ayudar en la toma de decisiones. No hay que olvidar que este método busca tendencias futuras basándose en entrevistas con expertos, pero no dibuja el estado de la opinión pública. Se puede decir que, aplicada al prospectivismo, representa una herramienta de anticipación prospectiva que conjuga aspectos de técnicas de investigación social tradicionales como la tormenta de ideas, entrevistas personalizadas, reuniones de grupo o encuestas.

Los rasgos característicos de la técnica Delphi son, según los expertos en prospectiva: 
Es una técnica de análisis del estado de opinión, derivada de la tradicional reunión de grupo, cuyo objetivo es el consenso.

El grupo consultado es un conjunto de expertos cualificados para opinar acerca del desarrollo futuro del objeto de estudio.

Todo el proceso es dirigido por un coordinador o conductor que es el enlace entre los expertos consultados.

Los componentes del grupo desconocen quiénes son sus compañeros de debate; el anonimato es preservado por la distancia y garantizado por el conductor del proceso.

El proceso se realiza sobre la base de una sistémica predeterminada: la información es recabada mediante cuestionario, que se acompaña en cada fase (de las varias consideradas) con una retroalimentación informativa.

Las cuestiones contenidas en el cuestionario, aun siendo de naturaleza cualitativa, son planteadas de forma que sea posible su medición cuantitativa.

La alternancia de fases, en las que se combina un cuestionario cada vez más cerrado con información de los resultados obtenidos en la fase anterior, conduce inexorablemente a la obtención de un consenso.

El coste (en tiempo y recursos) de la "reunión virtual" que propugna el Delphi es mucho menor que el de una reunión de grupo convencional, dado que, aparte de que la obtención de consenso es segura, se economiza tiempo dado que a lo largo de todo el proceso nada escapa de control.

Facilita la conjunción de opiniones de expertos relevantes respecto de la reunión de grupo, dado que la consulta se hace a distancia. Hoy día la conducción de un Delphi, aun cuando el grupo de expertos esté distribuido por los cinco continentes y sea a priori de difícil acceso, no sólo es factible sino mutuamente fácil y económica. Las nuevas tecnologías de comunicación (telecomunicaciones + ordenador personal), están haciendo que las "telencuestas" se estén convirtiendo en algo común entre las organizaciones, en concreto, el correo electrónico posibilita el acceso inmediato y la elaboración de listas de distribución. 
Los métodos de la hermenéutica nos ayudan a entender el presente tras el análisis de los textos históricos. Éstos serían: análisis literal, histórico, teleológico, sistemático y lógico.

La prospectiva, en palabras del profesor de Sociología de la Universidad de Alicante (España) Enric Bas, se presenta como un método de trabajo basado en la previsión que puede orientar la gestión organizacional a través de la detección de futuribles y la determinación de alternativas de actuación, contribuyendo de esta forma a la reducción de la incertidumbre y la minimización del coste de oportunidad que conlleva el diseño de las estrategias.

La incertidumbre 10 no ha de ser entendida en su concepto químicamente puro, es decir, el físico, pero la idea que nos produce es similar al aplicarlo a la Sociología. En cuanto al coste de oportunidad, conviene recordar que aquí sí nos hallamos ya ante un concepto puramente perteneciente a la mercadotecnia pues lo podemos definir como el cálculo de todos los costes y beneficios posibles asociados a un proyecto. También se utiliza para analizar los efectos de seguir adelante con un proyecto o, por el contrario, anularlo.

El análisis u oportunidad de negocio se utiliza mucho para evaluar los proyectos que quiere realizar el sector público, porque esta modalidad de análisis no sólo tiene en cuenta los costes y beneficios económicos, sino también los costes y beneficios sociales que tendrá el proyecto. Es un análisis muy complejo puesto que no existe ningún precio de mercado que mida los efectos sociales. Por ejemplo: ¿cómo se pueden medir los costes asociados con el aumento del riesgo de accidentes, el impacto ecológico, la destrucción de un paraje natural o el aumento de la contaminación cuando se construye una carretera? ¿Cómo se pueden medir los beneficios económicos que se podrán obtener gracias a esta nueva vía de comunicación? El análisis de oportunidad (política también, como hemos visto) se 
aplica para escoger entre distintas opciones, como por ejemplo, entre crear una nueva autopista o un aeropuerto pero, como nunca se podrán determinar con exactitud los costes sociales, la decisión final dependerá tanto de consideraciones políticas como de los resultados del análisis coste-beneficios puramente económicos.

Sin saberlo, el prospectivismo ofreció sus primeros pasos al mundo político desde el protoimportante campo de la econometría; su adelantado: Jhon M. Keynes. Tras la I Guerra Mundial, las potencias beligerantes se reunieron en Versalles (Francia) en 1920 para decidir las compensaciones de guerra. Los intereses estaban planteados desde el desquitismo de los vencedores que sufrieran la guerra más directamente sobre sus territorios o población y la prudencia de aquéllos que sufrieron menos el impacto bélico directo, como los británicos o los estadounidenses. La cantidad que se barajaba para Alemania, única potencia tomada como responsable del conflicto, era de 33.000 millones de dólares de la época. En la delegación británica se encontraba un profesor de economía de Cambridge de 36 años que se oponía con firmeza a las sanciones ya que predijo: "En Alemania se desincentivará la inversión y el empleo". Coherente con sus ideas y viendo el nulo caso que se le hacía abandonó la legación británica y volvió a Cambridge. Escribió dos libros con sus predicciones titulados Una revisión del Tratado y Consecuencias económicas de la paz. Sus predicciones se cumplieron: En 1925 se redujo en un 80\% las indemnizaciones lo cual lo rehabilitó políticamente. Hoy lo recordamos por ser el precursor de otra institución internacional por él vaticinada: El Fondo Monetario Internacional y su celebérrimo Banco Mundial. Se demostró una vez más que el futuro se podía predecir en algunos aspectos con bastante precisión. Cuando miramos hacia atrás, hasta el lejano 1900 y resumimos la historia en gráficos con la visión de autosuficiencia que poseen quienes afirman saber que casi todo se veía venir y que ya lo habían predicho, nos asalta una duda: ¿Si se hubiera aplicado la prospectiva al más puro estilo de Keynes desde el siglo XIX se hubieran podido evitar los hechos negativos que ahora vemos tranquilamente desde nuestras butacas como un cuadro sinóptico? ¿Cómo saber si 
dos países mejorarían en el ámbito social tras su unión cuando sí se sabe positivamente que mejorarían en el económico? Las Opiniones Públicas puede que no estén preparadas mayoritariamente, apostando más por los aspectos negativos, que sin duda también existen, que por lo que de positivo conllevan. La función de los Publirrelacionistas es preparar un camino cuyo final quizá no alcancen a ver ellos mismos, pero sí sus nietos. Sobre sus espaldas recae la responsabilidad de reinventar el futuro.

Las empresas o compañías también utilizan este tipo de análisis. Además de calcular la viabilidad de un proyecto en función de las distintas situaciones posibles, es decir, las que se mueven dentro del gradiente: muy probables-probables-poco probables, se tienen en cuenta otro tipo de factores, no siempre calculables, como las reacciones de los trabajadores al tener que cambiar de lugar de trabajo. El análisis de los costes de oportunidad de distintas alternativas se plasma, por ejemplo, en si se comparará la pérdida de ingresos asociada con no emprender una nueva actividad con la pérdida de ingresos que se producirá si se emprende la misma, en lugar de ingresar el dinero en una cuenta bancaria recibiendo a cambio un determinado tipo de interés, tal y como nos recuerda el maestro de maestros Paul Samuelson, padre de la Escuela de Chicago.

El gran enemigo del emprendedor de hoy, tanto en el campo de decisiones políticas como en el de las empresariales y económicas es el análisis emotivo.

El ser humano se mueve por: Interés, Necesidad y Prejuicio 11. Sólo éste último factor se escapa al control inmediato del raciocinio.

Cuentan que cuando uno de los principales consejeros del Presidente Estadounidense Ronald Reagan fue inquirido por él sobre cómo vencer al archienemigo y fantasma de los Estados Unidos, es decir, al "imperio del mal" 
soviético, éste le contestó: "Asfixiándolos económicamente". Hoy en día el carísimo proyecto de Defensa Estratégica, más conocido como "Guerra de las galaxias", de cuya segunda parte vamos a tener el privilegio de ser testigos de excepción gracias al Presidente Bush (hijo), es la cortina visible de un profundo cambio socioeconómico del planeta. El único modelo de sistema se ha impuesto y no va a permitir cambios en el status quo emergente tras el desmoronamiento del comunismo.

La prospectiva afirma que los soviéticos hubieran ganado en los años 60, 70 y parte de los 80 una guerra mundial contra los Norteamericanos ya que estaban acostumbrados a sufrir grandes calamidades en su propia tierra, cosa que los estadounidenses no hubieran soportado (recuérdese el revuelo en la Opinión Pública tras la caída de las Torres Gemelas del Centro World Trade). El pueblo ruso es más duro y su tecnología por aquél entonces era equiparable aunque no tan sofisticada. No dieron el paso porque no es un pueblo belicista. Quizá en un futuro se les obligue a dar ese paso definitivo y fatal para la especie humana, sólo que entonces no podrán resultar vencedores, pese a que caminen de la mano china presumiblemente. La realidad jugó del lado del mundo libre occidental.

Pero cuidado: F. W. Nietzsche 12 nos advirtió del eterno retorno de lo idéntico para que el hombre se autoafirme y se supere a sí mismo. Los políticos ya han tomado nota y esto lo hemos podido comprobar en numerosos ejemplos recientes, como lo sucedido tras la crisis bursátil del 1987, en la que los Estados no permitieron bajas electrizantes ni derrumbamientos apocalípticos propios del libre mercado como allá por el 1929.

La prospectiva nos adelanta pasos ya hollados encuadrando los acontecimientos en 5 tipos de tendencias o datos temporales que se pueden analizar y extrapolar. En palabras del profesor Jordi Serra las tendencias se podrían definir como corrientes 
que hemos cartografiado y cuyo desarrollo futuro podemos anticipar e inicialmente en un primer momento citaré:

Estables: Aquéllos que no cambian con el tiempo, o lo hacen casi imperceptiblemente, como distancia del Sol a la Tierra...

Cíclicos o de vaivén: Los conforman los fenómenos que se repiten periódicamente, como las estaciones, los días y noches, las mareas, la moda, las costumbres, los gobiernos de izquierdas y derechas en un mismo país...

Exponenciales: Formado por los acontecimientos que sufren crecimientos o reducciones muy marcados o drásticos, como la población mundial, las reservas de petróleo, las religiones...

Orgánicos o logísticos: Propias de los acontecimientos con crecimiento inicial muy rápido hasta llegar a un techo marcado por una limitación externa que estabiliza su desarrollo. Este ciclo en forma de "S" puede hallar continuación en un nuevo crecimiento ya sostenido, ya explosivo o en un estancamiento muy prolongado o en una mengua sostenida o explosiva. Típico de los imperios, las revoluciones políticas, las tecnologías, los nuevos productos en mercadotecnia...

Factores emergentes: Son las tendencias totalmente nuevas, procesos o sistemas dinámicos que cambian el entorno radicalmente y que basan su emergencia en que no han sido experimentados previamente por la humanidad como las revoluciones tecnológicas en general, la televisión, los nuevos descubrimientos geográficos o científicos...

No olvidemos que, así como las adivinaciones y profecías nos ofrecen certezas absolutas sobre el futuro pues las aseveraciones proféticas no son discutibles ya que 
anuncian lo que va a pasar inexorablemente, la prospectiva siempre trabaja con niveles de posibilidad. El futuro vaticinado por dichas adivinaciones es una promesa de realidad verdadera, es decir, no hay elección pues este futuro sólo uno, inexorable y no cambiable 13. La prospectiva, en cambio, permite dar pistas de cómo cambiar los futuros, en plural, ya que todos ellos son posibles pero más o menos probables. Haremos que los negativos, no deseables o poco claros frente a otras opciones de porvenir, se puedan minimizar, descartar o hacer menos probables gracias a los pilares que edificamos en el hoy.

Esta distinción es crucial, en palabras de Jordi Serra, puesto que si existe más de un futuro tendremos la oportunidad de elegir mediante nuestros actos. Es decir, se nos permite cambiarlo, muy otra es que conozcamos la forma exacta y precisa de cómo llevarlo a cabo.

Según los trabajos de uno de los primeros teóricos de la prospectiva, Bertrand de Jouvenel: "si el futuro está prefijado, podemos llegar a conocerlo; pero si lo conocemos por anticipado, lo podemos cambiar, y si podemos cambiarlo, es que ya no lo conocemos".

La prospectiva vuelve a dar importancia al libre albedrío humano frente al determinismo absoluto o el indeterminismo aleatorio, sus dos antítesis naturales. Hablamos, claro está de escenarios posibles y probables.

El hoy profesor de la Universidad de Hawai James Allen Dator comenzó este camino desde la oficina de futuros problemas jurídicos creada por el Tribunal Superior de Hawai.

Si aplicamos la escala anterior de "formas del futuro" a la relación hispano-lusa nos hallamos claramente ante un caso de los denominados cíclicos. 
6- Teoría del caos: Teoría matemática que se ocupa de los sistemas que presentan un comportamiento impredecible y aparentemente aleatorio aunque sus componentes estén regidos por leyes estrictamente deterministas. Desde sus comienzos en la década de los 70, la teoría del caos se ha convertido en uno de los campos de investigación matemática con mayor crecimiento. Hasta ahora, la física, incluso si se consideran las ramificaciones avanzadas de la teoría cuántica, se ha ocupado principalmente de sistemas en principio predecibles, al menos a gran escala; sin embargo, el mundo natural muestra tendencia al comportamiento caótico. Por ejemplo, los sistemas meteorológicos de gran tamaño tienden a desarrollar fenómenos aleatorios al interaccionar con sistemas locales más complejos. Se popularizó la consigna "caótica" mediante la frase citada incluso en la película "Parque Jurásico" <1.993> de Steven Spielberg: "Una mariposa bate sus alas sobre Pekín y llueve en Nueva York". Otros ejemplos son la turbulencia en una columna de humo que asciende o el latido del corazón humano. Durante mucho tiempo, los científicos carecieron de medios matemáticos para tratar sistemas caóticos, por muy familiares que resultaran, y habían tendido a evitarlos en su trabajo teórico. A partir de la década de los 70, sin embargo, algunos físicos comenzaron a buscar formas de encarar el caos. Uno de los principales teóricos fue el físico estadounidense Mitchell Feigenbaum, quien determinó ciertos esquemas recurrentes de comportamiento de los sitemas que tienden hacia el caos, esquemas que implican unas constantes ahora conocidas como números de Feigenbaum. Los esquemas del caos están relacionados con los que se observan en la geometría fractal, y el estudio de sistemas caóticos tiene afinidades con la teoría de catástrofes.

7- Teoría de catástrofes: Término que designa el intento de desarrollar un sistema matemático capaz de representar fenómenos naturales discontinuos que no son descritos satisfactoriamente por el cálculo diferencial. Un ejemplo de "catástrofe" 
puede ser la rotura súbita de una pieza de metal bajo presión. La teoría de catástrofes fue presentada en 1968 por el matemático francés René Thom, y atrajo a muchos investigadores en la década de los 70. Se intentó aplicar esta teoría para describir fenómenos discontinuos de las ciencias sociales y biológicas, pero hoy está en desuso por ser poco práctica.

8- Casandra: Mitología griega. El dios Apolo, que amaba a Casandra, le concedió el don de la profecía, pero cuando ella se negó a corresponder a su amor, Apolo volvió inútil el don haciendo que nadie creyera en sus predicciones. Casandra advirtió a los troyanos de muchos peligros, incluso del caballo de madera con el que los griegos entraron en la ciudad, pero fue desestimada como una loca. Casandra fue entregada al rey Agamenón como su esclava y amante. Casandra le advirtió de que sería asesinado si volvía a Grecia, pero de nuevo no obtuvo crédito. A su llegada a Micenas ella y Agamenón fueron asesinados por Clitemnestra, esposa de éste y reina de Micenas.

9- Heródoto o Herodoto: (c. 484-425 a.C.) Historiador griego, reconocido como el padre de la historiografía. Dedicó su vida a completar su gran obra, conocida como Historias, cuyo título deriva de la palabra griega historia ('investigación', 'búsqueda'). Los estudiosos de Historias la dividieron más tarde en nueve libros. Los primeros tratan sobre las costumbres, leyendas, historia y tradiciones de los pueblos del mundo antiguo, incluidos los lidios, escitas, medas, persas, asirios y egipcios. Los tres últimos versan sobre los conflictos armados entre Grecia y Persia que tuvieron lugar a principios del siglo V a.C. y que son conocidos como las Guerras Médicas. La información de Heródoto procede en parte de los trabajos de sus predecesores y en parte de las observaciones que hizo durante sus extensos viajes. Sus Historias son el primer trabajo importante en prosa. Creía que el Universo estaba regido por el destino y el azar, y que nada en los asuntos humanos es estable. Sin embargo, la elección moral seguía siendo importante, ya que los dioses con frecuencia castigan la 
arrogancia. Este intento de extraer lecciones morales del estudio de los grandes acontecimientos, es la base de la historiografía griega y romana.

10- Principio de incertidumbre: En mecánica cuántica, principio que afirma que es imposible medir simultáneamente de forma precisa la posición y el momento lineal de una partícula, por ejemplo, un electrón. El principio, también conocido como principio de indeterminación, afirma igualmente que si se determina con mayor precisión una de las cantidades se perderá precisión en la medida de la otra, y que el producto de ambas incertidumbres nunca puede ser menor que la constante de Planck, llamada así en honor del físico alemán Max Planck. La incertidumbre es muy pequeña, y resulta despreciable en mecánica clásica. En cambio, en la mecánica cuántica las predicciones precisas de la mecánica clásica se ven sustituidas por cálculos de probabilidades. El principio de incertidumbre fue formulado en 1927 por el físico alemán Werner Heisenberg y tuvo una gran importancia para el desarrollo de la mecánica cuántica. Las implicaciones filosóficas de la indeterminación crearon una fuerte corriente de misticismo entre algunos científicos, que interpretaron que el concepto derribaba la idea tradicional de causa y efecto. Otros, entre ellos Albert Einstein, consideraban que la incertidumbre asociada a la observación no contradice la existencia de leyes que gobiernen el comportamiento de las partículas, ni la capacidad de los científicos para descubrir dichas leyes.

11- La palabra prejuicio, en español, posee un matiz popular negativo. Se aplica siempre a situaciones en las que el sujeto sobre quien se posee está en perspectiva negativa frente a quien emite el juicio u opinión. No ha de ser así y en estas páginas ha de ser entendido stricto senso, es decir, "pre - juicio" o juicio previo, tanto para bien como para mal, sin determinismo en su significado.

12- Friedrich W. Nietzsche: (1844-1900) Estudió filología clásica en las universidades de Bonn y Leipzig, y fue nombrado profesor de filología griega en la Universidad de 
Basilea a los 24 años. Además de la influencia de la cultura helénica, en particular de las filosofías de Sócrates, Platón y Aristóteles, Nietzsche estuvo influenciado por el filósofo alemán Arthur Schopenhauer, por la teoría de la evolución y por su amistad con el compositor alemán Richard Wagner. Escritor prolífico, escribió varias obras importantes, entre ellas El origen de la tragedia (1872), Así habló Zaratustra (18831885), Más allá del bien y del mal (1886), La genealogía de la moral (1887), El crepúsculo de los dioses (1888), El Anticristo (1888), Ecce Homo (1889) y La voluntad de poder (1901). Uno de los argumentos fundamentales de Nietzsche era que los valores tradicionales habían perdido su poder en las vidas de las personas, lo que llamaba nihilismo pasivo. Nietzsche afirmó el imperativo ético de crear valores nuevos que debían reemplazar los tradicionales, y su discusión sobre esta posibilidad evolucionó hasta configurar su retrato del hombre por venir, el 'superhombre'. De acuerdo con Nietzsche, las masas (a quien denominaba "rebaño", "manada" o "muchedumbre") se adaptan a la tradición y la historia se presenta en ciclos que se repiten hasta el infinito, en un eterno rotar que llamó "eterno retorno de lo idéntico". Nietzsche sostenía que todo acto o proyecto humano está motivado por la "voluntad de poder".

13- Otro ejemplo cinematográfico: "Terminator II" <1992> de James Cameron trata de los desvelos de un mujer que conoce el futuro, lo entiende como inexorable y para cambiarlo de raíz va a matar al futuro culpable. "Minority report" la nueva película de Spielberg en actual proceso de rodaje (cuyo estreno se prevé para fines de 2002) trata sobre una brigada de policías que detienen a los culpables antes de que cometan el delito, pues una máquina es capaz de detectar los hechos venideros de índole delictiva. 


\section{La prospectiva aplicada}

\subsection{Guerra Árabe-Israelí}

Uno de los ejemplos más claros de aplicación de la prospectiva en temas políticos pueda ser el eterno conflicto árabe-israelí ya desde tiempos de la descolonización británica de aquellas tierras tras la II Guerra Mundial.

Surgida Palestina de la desmembración del Imperio Otomano, perdedor de la I Guerra Mundial, y sumido en una paz que le obligó a reducir drásticamente sus territorios hasta configurar lo que hoy conocemos como Turquía, ha supuesto para la comunidad internacional una inagotable fuente de conflicto y de amenaza para la pax europea $\mathrm{u}$ occidentalis ( al estilo de la pax romana) de la que goza nuestro continente. La subida de un par de Euros simplemente en un barril (159 litros) de petróleo puede sumir a las economías occidentales en una era de recesión con paro, estancamiento social y económico y algaradas políticas. Aún no se plantearía la posibilidad de revolución pues el factor tiempo es decisivo en este último y radical paso.

Los hechos hablan por sí mismos:

1896. Teodoro Herlz, padre del sionismo político, escribe El Estado judío, donde expone que el antisemitismo sólo se resolverá creando un Estado Hebreo.

1917. La Declaración de Balfour promete el apoyo británico al establecimiento de un hogar nacional judío en Palestina.

1948. Se crea el Estado de Israel. El nuevo país se enfrenta a Egipto, Jordania, Siria, Líbano e Irak en la primera guerra árabe-israelí.

1956. Segunda guerra árabe-israelí: Israel captura la Franja de Gaza y la península del Sinaí. 
1967. Tras la Guerra de los Seis Días (6-11 de junio), Israel controla Judea, Samaria, Gaza y la península del Sinaí.

1978. Israel y Egipto firman ante el Presidente Jimmy Carter los Acuerdos de Camp David (Estados Unidos) bajo la consigna "Paz por Territorios".

1987. Comienza el levantamiento palestino (Intifada).

1993. Rabin y Arafat firman la Declaración de Principios, un acuerdo interino para el autogobierno palestino en Cisjordania y Gaza.

Está claro que si el origen del conflicto no se ha solventado, los rebrotes han de ser constantes. ¿Cómo se producirán éstos en un futuro próximo?. La prospectiva política aboga por la creación de un estado palestino independiente como primer paso. A la larga, si nos atenemos al repunte religioso radical que tinta todo el proceso (recuérdese el caso de los Talibanes en Afganistán), se puede anunciar la desaparición del Estado de Israel, aunque no sólo de éste, pues se prevé una cruentísima guerra contra sus mucho más numerosos enemigos, en la que alguno de ellos también sucumbirá (Jordania, Siria y Líbano con grandes probabilidades).

Los factores de presión demográfica, económico y religioso han demostrado que nunca han podido ser contenidos racionalmente, y en una guerra total, los seis millones de israelitas no son enemigo suficiente para los más de trescientos de musulmanes que los cercan.

\subsection{Un ejemplo para la educación superior}

Quizá una de las aplicaciones más lógicas y más interesantes para los docentes de la educación universitaria es la que se llevó a cabo en 1994 en la Universidad mexicana de Regiomontana (Monterrey). Envueltos allí, como suele suceder en todos los países cíclicamente, en una reforma universitaria que parece perenne, se plantearon discernir cuál iba a ser el futuro de la educación para ofertar a sus alumnos venideros 
unos planes de estudio o currícula más atractivos y realistas. Su proyecto fue llamado Modelo Educativo UR 2000, ya que la idea era mejorar paulatinamente en un plan continuado y nada rupturante hasta tan emblemática fecha; sentando las bases, de entre todos los futuros posibles, del más preferible para la educación universitaria.

El actual Modelo UR 2000, es en realidad el importante resultado de la aplicación del Estudio de los Futuros. En sus propias palabras y a modo de declaración de intenciones: "En el año de 1994 iniciamos un gran esfuerzo institucional para analizar las experiencias acumuladas con los modelos educativos tradicionales e identificar las principales tendencias en la educación superior y en otros frentes en cualquier parte del mundo para integrarlas como aspiraciones de un nuevo modelo".

Los principales resultados fueron los siguientes:

En cuanto a los modelos educativos tradicionales:

Se centran en la adquisición de conocimientos,

El maestro planea lo que habrá de enseñar, y

Evalúa el aprendizaje de sus alumnos mediante exámenes.

Predomina el concepto de la clase,

Dictada por el maestro, dentro de un salón

$\mathrm{Al}$ que asisten los alumnos para tomarla.

Se supone que todos los alumnos, tienen la motivación suficiente

Para cumplir con sus obligaciones rutinarias, $\mathrm{y}$

Si lo hacen reciben como premio una calificación aprobatoria.

Aún así, existen maestros excelentes que facilitan para sus alumnos las más significativas experiencias de aprendizaje y les transmiten valores y actitudes útiles para toda la vida. 
En cuanto a las tendencias en la educación superior y en otros frentes, que pretendían integrar:

Se centran en el desarrollo de competencias para el trabajo y para la vida,

El maestro planea los aprendizajes que después habrá de facilitar, y

Evalúa el aprendizaje de sus alumnos mediante las participaciones, colaboraciones y demostraciones.

Predominan los conceptos de estrategia de transferencia y de actividad de aprendizaje,

Realizadas por los alumnos con la facilitación del maestro, en el salón de clase, en un lugar de trabajo, en cualquier otro lugar físico o desde una computadora en red a través de interacciones virtuales o en línea,

Mediante las cuales los alumnos generan e integran los conocimientos, habilidades, actitudes y valores.

Se supone que todos los alumnos, y el propio maestro, tienen la responsabilidad y el interés suficientes,

Para generar y mantener la participación intensa y motivadora dentro de un equipo colaborativo,

Dando como resultado el desarrollo de las competencias clave para la vida y para el trabajo, y

Dentro de esas competencias; las necesarias para el auto-aprendizaje a lo largo de toda la vida.

Conclusiones: Si en los sistemas educativos tradicionales se utilizan los libros de texto, ésta nueva versión del mismo no puede equivaler otra vez a un simple libro de texto al uso como los de antes. Tampoco es un manual para el maestro, ni una colección de materiales didácticos o contenidos temáticos, ni un cuaderno de trabajo para el alumno. Pretende ser, es, una combinación de todo lo anterior para apoyar la integración del discurso metodológico del Modelo UR 2000 con el discurso temático 
de las Tendencias de la Sociedad Actual o el Estudio de los Futuros. Y esto dentro de la planeación de un proceso educativo que satisfaga las aspiraciones de nuestro modelo y con ello, sólo con ello, los objetivos de este curso en particular, que son un conjunto de competencias específicas, según sus deseos.

Pretendieron traer al presente lo que consideraron, en sus propias palabras el estilo de la educación universitaria del futuro, lo importante es que aplicaron técnicas prospectivistas para ello, aunque en fase inicial.

\subsection{Iberismo}

“Castellanos y portugueses que españoles somos todos" (Luis Vaz de Camões, $<1524-1580>) 14$

“Veréis luego a la invicta y noble España

por cabeza de Europa señaladla,

en cuya gloria la fatal y extraña

rueda mil vueltas dio por humillarla;

mas no podrá jamás con fuerza o maña

la Fortuna inquieta derribarla,

que la ensalza el esfuerzo y osadía

de los valientes hombres que en sí cría".

(Canto III, estrofa XVII de Los Lusíadas de Luis Vaz de Camões, <1524-1580>)

En un mundo que habla casi exclusivamente en sajón, los latinos europeooccidentales desde fines del siglo XVII venimos sufriendo la falta de previsión de nuestros ancestros. Y las Relaciones Públicas pueden y deben crear estados positivos en la Opinión Pública de nuestros países para que por evolución natural se considere lógico, correcto y sobre todo conveniente la unión entre países hermanos. 
La Unión Europea no ha sido más que una amalgama de países unidos por un deseo centroeuropeo de paz (Eje Berlín-París) tras dos sangrientas guerras cuasi-europeas llamadas mundiales por nuestro Eurocentripetismo.

La Opinión Pública fue ganada de antemano ya que la Unión convenía políticamente aunque en un análisis sociológico de fondo hallamos que, curiosamente, estamos hermanados con bárbaros rubios del norte que cenan sopa de col agria a las cinco de la tarde. Pero por fin: "Ya somos todos Europeos".

Irónicamente Checoslovaquia se disgrega en Chequia y Eslovaquia tras una decisión política que no se vio secundada por las encuestas realizadas entre los ciudadanos del país que creían ser más importantes en la escala mundial siguiendo unidos, pero que no estaban dispuestos a luchar frente al poder político por imponer su voluntad. Vox populi, vox dei.

Nunca faltan vates y augures que profeticen sobre los males y bienes que traerá consigo el futuro; ni videntes que "ya lo veían venir" y que "ya nos habían advertido". La prospectiva es la respuesta técnicamente más completa que hasta hoy se ha propuesto desarrollar y aplicar la comunidad científica a ese país desconocido que llamamos futuro.

La actual expresión geográfica de Hispania (cuyo significado es tierra de conejos) se reduce hoy en exclusiva y simplísticamente a un país, heredero del nombre fenicio de la Península Ibérica, España. Los hijos de Lusus, los Lusíadas, también adoptaban el nombre de Españoles frente a los pueblos ultra pirenaicos o de allende Europa.

La Monarquía Hispánica, que tan mala imagen ha suscitado en alguno de los pueblos que la conformaron, gracias debidas en gran parte a la historiografía británica, es la precursora de lo que hoy todos alaban como "Tratado de Maastricht"15 
O tempora o mores (¡Oh tiempos, oh costumbres!), se lamentaba Marco Tulio Cicerón y si bien addenda et corrigenda, la historia dibuja culpables, absuelve inocentes y juzga a todos, está claro que si no la letra, sí el espíritu universalista hunde sus huellas en el horizonte político europeo desde el Tratado de Roma. Eso sí, las figuras del abogado defensor y del fiscal son determinantes a la hora de alcanzar un veredicto de inocencia o culpabilidad para con un país, un gobernante o una idea.

Repasando la historia comprobamos que:

Si trazáramos una línea temporal veríamos como en los últimos 2100 años, aproximadamente, sólo ha habido separación entre los dos territorios durante unos setecientos años, frente a los mil cuatrocientos de unidad y los venideros a partir de la integración común en Europa. Veámoslo en un cronograma para observar su magnitud. (No está a escala)

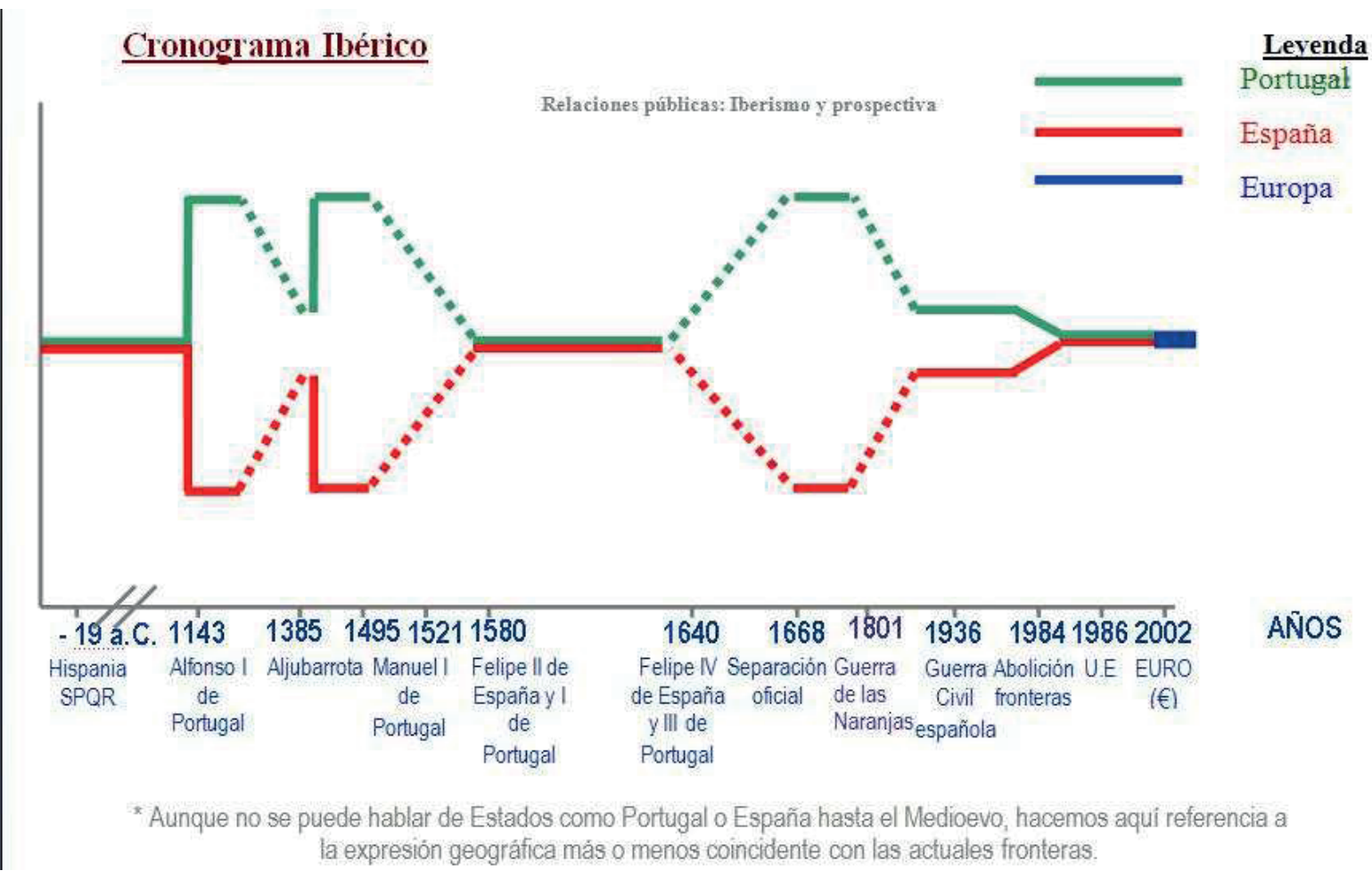


Curiosamente y heredado de aquellos tiempos, la ciudadanía española se mantiene muy accesible para los ciudadanos de los países de la América española, Filipinas, Guinea Ecuatorial, Andorra y Portugal, además de los judíos sefardíes cuyos apellidos se estudian para comprobar su autenticidad. A estos ciudadanos se les exige únicamente la residencia de dos años en territorio español frente a los diez en todos los demás casos.

Esta tendencia nos ha de hacer reflexionar obligatoriamente, y más cuando si cualquier ciudadano español desea adquirir otra ciudadanía se ve obligado a perder la española excepto, de nuevo, en el caso de los países anteriormente citados cuya nacionalidad (la adoptada) se complementa con la española dándose la figura legal de la doble nacionalidad.

14- Luis Vaz de Camões: (1524-1580) Uno de los más grandes poetas portugueses, cuya obra principal, Os Lusíadas (Los Lusíadas, 1572), se considera el poema épico nacional portugués. En 1553, embarcó para la India. El argumento central del poema es el descubrimiento de la ruta marítima a la India por el explorador portugués Vasco da Gama. Os Lusíadas, escrito en diez cantos en octava rima, se inspira tanto en la Eneida, el poema épico de Virgilio, como en Orlando furioso, de Ludovico Ariosto. Enlazadas con la historia del viaje de Vasco da Gama aparecen intensas referencias narrativas y proféticas a otros acontecimientos de la historia de Portugal, y también a determinadas ideas cristianas y humanistas. La obra ensalza las hazañas de los hijos de Lusus esto es, los Lusíadas, o portugueses. Es notable su perfección y simplicidad formal, la expresión de un sentimiento profundo y la introducción de un nuevo tema en la literatura portuguesa, la saudade-soledade ("añoranza cargada de soledad"). 
15- Tratado de Maastricht: Nombre por el que es más conocido el Tratado de la Unión Europea, aprobado en Maastricht (Holanda) por los doce jefes de gobierno de la Comunidad Europea (ahora Unión Europea) en diciembre de 1991 y firmado el 7 de febrero de 1992. El Tratado estableció una política exterior y otra monetaria comunes, y proyectó la creación de un banco central para el año 1999. En general reflejó la intención de la Unión Europea de ampliar la escala de la unión económica y monetaria y de iniciar una seria consideración sobre unas políticas comunes de defensa, de ciudadanía y de protección del medio ambiente. Maastricht representa un gran desarrollo y, a la vez, una modificación del Tratado de Roma, por lo que se refiere a la estructura organizativa de la Unión Europea; su aprobación originó numerosos conflictos económicos y políticos dentro de los estados de la Unión Europea así como entre unos y otros. Dinamarca y el Reino Unido se mostraron muy poco dispuestos a renunciar al control nacional de sus respectivas políticas monetarias. Como consecuencia, se reconsideraron los objetivos más ambiciosos del Tratado y se amplió la fecha límite para la unión monetaria.

\section{La prospectiva inversa}

La prospectiva inversa es la herramienta que sirve para preparar el futuro según los intereses que consideremos éticamente más adecuados para una persona, una ciudad, una organización o un país, por proponer aplicaciones cercanas.

El ejemplo más claro al respecto, sin caer en el tópico de la profecía que se cumple a sí misma aunque hayamos claros elementos de este tipo de situaciones siempre que esté en manos de las personas que las emiten su consecución (con lo que hablaríamos de "juramentaciones" más que de profecías al uso) fue la promesa del presidente estadounidense J. F. Kennedy de que el hombre hollaría con su pie la superficie lunar antes de 1970. Este pronóstico, igual en contenidos a los de Julio Verne, se basaba en 
la confianza en el potencial, en la capacidad de esfuerzo y en la inteligencia puesta al servicio de un objetivo nacional.

Palabra presidencial empeñada, prestigio nacional en juego, recursos económicos altos, voluntad y deseo de vencer al enemigo y Opinión Pública favorablemente entusiasta, se conjugaron hasta el 21 de julio de 1969. M. Collins, Edwin E. Aldrin y el pie de Neil A. Armstrong pusieron el resto

Las voces que apuntan a que el hombre no alunizó achacando todo a una campaña de imagen de la NASA (Agencia Aeroespacial Estadounidense), ayudaron a revitalizar la noticia en la década de los 80 y 90.

El método o camino hay que entenderlo ahora, en la prospectiva inversa, como un descontar de pasos. Sabiendo donde está la meta se trata de idear la vía sabiendo el punto de partida. Al conocer el Alfa y la Omega de su ruta se puede trazar matemáticamente la línea recta o vía más corta para arribar. Muy distinto es que esta línea recta sea el mejor de los caminos ya que raramente coincide la cortedad de la distancia con la facilidad en el recorrido; e, incluso, yendo más lejos podemos afirmar que suelen ser valores inversamente proporcionales generalmente.

Sea deseado o no, el paso del tiempo nos trae futuros que tienen una característica en común entre ellos: Todos se basan en el cambio.

El único futuro "no posible" es aquél que se basa en el "no cambio"

Un ejemplo: hace 30 años ningún español o portugués hubiera creído que, con Franco o Marcelo Caetano aún en el poder, caería el muro de Berlín; gobernarían los Partidos Socialistas ibéricos; que el entonces "terrorista" Nelson Mandela llegaría a la presidencia de la Republica Surafricana; que los ordenadores serían de bolsillo al 
igual que los teléfonos; que crearíamos bebés a la carta; que Portugal, España, Francia, Italia y hasta la lejana Finlandia, entre otros, se unirían bajo la azul bandera europea, o que las Torres Gemelas, en construcción entonces, durarían menos de tres décadas en pie...

Según el director del Centro Catalán de Prospectiva Jordi Serra, a la sociedad actual, a diferencia de las anteriores a ella, no le sirve la experiencia como guía para tomar decisiones de futuro ya que los tres rasgos fundamentales de las sociedades contemporáneas son: la complejidad, la incertidumbre (lo cual trasladado a las personas hará que la depresión sea la mayor epidemia en el mundo más desarrollado durante este siglo) y la ignorancia de ser ignorantes.

La prospectiva traza el mapa dónde estamos y no nos plantea el futuro que ha de venir sino los futuros posibles para que pongamos las bases del cambio y lleguemos al más conveniente de ellos... Nos asalta la duda: ¿A juicio de quién?. Al nuestro ya que no hay otro en el que podamos involucrarnos.

Centrémonos en las leyes de Dator sobre el futuro, así llamadas por su creador, James Allen Dator 16 quien propuso bajo la base de que el estudio de los futuros no debe pretender estudiar "el futuro" sino estudiar ideas sobre el futuro, o, a fuer de exactos, sobre imágenes del futuro que cada individuo o grupo tiene, a menudo con algunos conflictos entre ellas, pero que sirven de base para la acción en el presente. Las imágenes del futuro tanto de los individuos como de las comunidades son a menudo muy volátiles, cambiando por razón de algunos eventos o por reubicación en la percepción. A menudo varían durante el tiempo de una vida. Grupos o comunidades diferentes generalmente tienen imágenes del futuro diferentes. Las imágenes de los hombres pueden ser distintas a las de las de las mujeres. Las de los occidentales difieren de las de los orientales... y así en muchas subdivisiones que podamos añadir y que sustancialmente presenten una variación de raíz o radical 
sobre una postura u opinión frente a una situación dada debido a factores de necesidad y/o interés como los: culturales, geográficos, económicos, religiosos o a los achacables al prejuicio, tercer pilar de la acción humana, como antes dijéramos.

Las Leyes del Futuro son:

$1^{\mathrm{a}}$.- "El futuro" no puede "predecirse", pero los "futuros alternativos" si pueden, y deben ser "pronosticados".

Por lo tanto, uno de los objetivos principales del estudio de los futuros es el de identificar y examinar los principales futuros alternativos que existen en cada tiempo y lugar.

$1^{a}$.a.- "El futuro" no puede "predecirse", pero los "futuros preferibles" si pueden, y deben ser visualizados, inventados, implementados, evaluados en forma continua, revisados y re-visualizados.

Por lo tanto, otro de los objetivos principales del estudio de los futuros es el de facilitar a los individuos y grupos la formulación, implementación y re-visualización de sus futuros preferibles.

Cualquier idea útil sobre el futuro debe parecer ridícula.

$2^{\text {a }}$ - Lo que es a menudo popularmente, o aún profesionalmente, considerado como "el futuro más probable", resulta ser uno de los menos probables.

$2^{\text {a }}$.a.- Si los futuristas desean ser de alguna utilidad, deben esperar ser ridiculizados e inicialmente rechazados por sus ideas. Algunas de sus ideas pueden merecer ser ridiculizadas y rechazadas, pero aún sus ideas útiles sobre el futuro podrían ser ridiculizadas.

$2^{\text {a }}$.b.- Por lo tanto, los tomadores de decisiones y el público en general, si desean obtener información útil sobre el futuro, deben esperar que ésta sea inconveniente y a menudo impactante, ofensiva y aparentemente ridícula. 
Los futuristas tienen el trabajo adicional de hacer que las ideas, que inicialmente parecían ridículas, sean consideradas factibles y operables proporcionando las evidencias apropiadas y proponiendo los escenarios alternativos que permitirían su desarrollo.

El fin es el mejor de los futuros, las Relaciones Públicas su herramienta.

La prospectiva representa un método sencillo: empleo de estadística y estudio de la posible evolución futura de los acontecimientos con la información que tenemos en el presente aplicando métodos científicos.

El economista polaco Ivan Bloch pronosticó el desarrollo y resultados de la I Guerra Mundial a partir de los datos que obtuvo de la guerra franco-prusiana de 1870. Trató datos como municionamiento, cadencia de fuego, bajas, heridos, población, capacidad industrial, avances tecnológicos armamentísticos, etc.

Pero este estudio "ingenuo" del futuro no lo es tanto si atendemos a la opinión de uno de los primeros prospectivistas: Gaston Berger: "La prospectiva es la ciencia que estudia el futuro para comprenderlo e influir en él". Para ser ciencia y que este apelativo no quede en mero nominalismo, ha de cumplir el precepto de los preceptos: Ser repetible partiendo de unos protocolos o métodos de trabajo conocidos y unos principios de aplicación. El corpus teórico-metodológico ha de ser común para toda la comunidad científica acotando los posibles campos de error y afinando los procesos para huir de toda aleatoriedad. 
16- James Allen Dator: Reconocido futurista, Fundador y Director del Hawai Research Center for Future Studies, y socio de Alvin Toffler dentro de la empresa Alternative Future Associates.

\section{Planes proiberistas y campañas de Relaciones Públicas}

Desde hace más de 8 años, vengo impartiendo la asignatura de "Fundamentos de las Relaciones Públicas" en la Facultad de Ciencias de la Información de la Universidad Complutense de Madrid. Desde entonces y uniendo esta asignatura a las de “Comunicación Interna de empresa” y la de “Organización y gestión del gabinete de comunicación", planteé a los alumnos la posibilidad de crear una célula de investigación para poder desarrollar las ideas que poco a poco iban corporizándose en la mente de los alumnos para complementar su formación en nuevas tendencias mercantiles, ya que la comunicación empresarial absorbe un cada vez mayor número de profesionales y yo no sólo como profesor podía orientarles sino también como empresario del sector comunicacional. Así creamos "Concilium".

Una de nuestras metas desde el comienzo fue plantear campañas de imagen sobre los temas que considerábamos de utilidad o interés para los españoles y que, años más tarde, podían ser susceptibles de convertirse en el quehacer diario de los graduados ya que su interés social hacia que fueran apetecibles para las grandes compañías de lobby, imagen y comunicación en las que muchos llegarían, o al menos eso esperaban, a trabajar.

El desarrollo de una campaña de imagen o de defensa de intereses legítimos, lo cual suele ser a veces concomitante, está muy planificado y diseñado por el marco teórico pero su aplicación práctica varía muchos enteros ya que la plasmación tiene un origen o arranque conocido pero una llegada accidentada y, las más de las veces, desconocida. 
Hace ya unos años uno de los temas propuestos para desarrollar durante el curso fue el Iberismo, o unión peninsular bajo identidades compartidas comunes. Al final no se estudió pues el epicentro de nuestra investigación pasó a ser las tan en boga legalizaciones de la eutanasia. Lástima, aunque no descarto para cursos venideros que el interés, siempre latente se patentice y podamos dedicarnos con detenimiento a estudiar y aplicar nuestros conocimientos prospectivistas a la magna tarea de volver a unir lo que a mi entender nunca se debió separar.

Lo que es cierto es que en un primer análisis epidérmico llegamos a la conclusión de que faltaban elementos (de lo que se deduce que hay carencia de voluntad) que nos aunaran, como:

la negativa española a co-organizar la Copa de Europa de Fútbol del 2004 (tal y como hicieran Bélgica y Holanda)

la extinta Copa Ibérica de fútbol

las nulas referencias meteorológicas en los boletines del tiempo ya que el clima de hoy en España mucho tiene que ver con el de ayer en Portugal

la ausencia en los informativos, incluso en los deportivos, de noticias de nuestros vecinos (lógicamente nos toca analizar la visión española sobre Portugal)

silencio cultural patente a excepción de Saramago, cuya residencia en suelo español sí se recuerda tal como los franceses hicieran con el malagueño Picasso

la guerra del fletán frente a Canadá que no sirvió para unirnos pese a ser los dos países más perjudicados...

Lo que sí quedó nítido a nuestros ojos es que podía haber detractores (pocos), entusiastas (bastantes más) y escépticos o poco interesados (la mayoría), pero lo que estaba claro es que jamás se plantearía la unión con otro país que no fuera Portugal (o Andorra, si cabe tildar a ese precioso principado pirenaico de país comparable con cualquiera de la Comunidad Europea). La respuesta a la unión con Francia era 
abrumadoramente rechazada y nunca justificada, con Gran Bretaña incluso ofensiva (aún colea el conflicto por Gibraltar), con Italia aparecía como más enraizada aunque la lejanía la hacía casi irreal, pero con Portugal, sí era cierto que la Opinión Pública tenía su interés y cierta tendencia, más bien positiva, a plantearla.

Ya que nuestros políticos han martilleado y percutido sobre nuestra concepción del mundo y de España y en especial de la bondad de la Comunidad Europea y el Euro, nos cabe preguntarnos, ¿Qué sería de nuestra común visión ibérica si nuestra clase dirigente desde hace décadas nos hubiera alabado y honrado al vecino?.. El que haya elementos importantes que nos separen:

\section{Olivenza,}

la mayor demografía y peso español en la futura unión,

el secular castellanocentrismo, incluyendo el idiomático al ser la lengua materna más hablada en la península (unos 30.000.000 frente a 11.000.000 de portugués, 6.000.000 de catalán-valenciano-balear, 2.000.000 de gallego, 500.000 euskera y 20.000 de astur-leonés),

competencia económica desde la industria hasta el turismo,

el nuevo centralismo administrativo que beneficiaría a la nueva capital en detrimento a la que perdiera este rango nacional,

las declaraciones comparativas de los políticos portugueses en los foros europeos sobre el mayor peso español, 5 delegados frente a 8 (lo cual daría 13 juntos, pero esto no se alienta ni potencia, sólo se remarca).

\section{Y anécdotas como:}

los gritos de "Ahora a Lisboa" ante Franco en el desfile de la victoria tras la guerra civil (Abril 1936). 
El trabajo fin de carrera en la academia militar de Francisco Franco: "La toma de Portugal en 28 días".

El estudio por parte del último gobierno de Franco en 1975 (con Arias Navarro como presidente de gobierno) de una invasión para frenar al comunismo luso.

las escasas votaciones en Eurovisión de un país a otro (Véase el caso de la armonía de los países bálticos o el odio turco-chipriota-griego).

El cañón de Elvas: ¡Ay Espanha si te moves!.

El dicho gallego: "Menos mal que aún nos queda Portugal"

El dicho portugués: "De Espanha nem bom vento nem bom casamento".

no hace más que reforzar la idea de la nula visión de futuro de nuestros ancestros. Por el contrario, sí aceptamos nuestro futuro común con los lapones, magiares, búlgaros, daneses y otros pueblos que ya pertenecen o están en vías de hacerlo a los Estados Unidos de Europa. Países soleados y veraniegos como Portugal y España con un nivel de renta por debajo del 85\% de la media europea (junto con Grecia, claro está), se codean con gigantes industriales y productivos como Alemania o Francia y con países con seis meses de noche perpetua y otros seis de día perenne, como Suecia, Noruega o Finlandia.

La prospectiva nos dice que este tipo de uniones, como la Europea, sólo funcionan en época de bonanza.

Dijo Su Majestad Carlos I de España y V del Sacro Imperio Romano Germánico que el idioma español estaba concebido para ser hablado con Dios. Quizá Dios no hable español, ni piense en portugués. Puede que no platique en latín, ni en griego clásico, ni se exprese fluidamente en hebreo ni tan siquiera mediante el más popular arameo, lengua materna de Jesucristo. Quizá Dios nos habla en matemáticas, sólo que no sabemos escucharle. 
Los romanos, al despedirse elevaban su mano y decían a su interlocutor "Bona auguria", o sea, "Buenos futuros" y Assimov nos enseñó que el futuro ya no es lo que era.

Desde aquí quiero hacer mío este buen anhelo para todos los presentes y hago votos por que aquéllos que podemos influir en el porvenir, lo hagamos guiados por el deseo del bien común, y recordar que sumar siempre obtuvo mejores resultados que restar. La prospectiva nos ayudará a domar este brioso corcel, este país desconocido al que llamamos futuro: Hispania capital Lisboa. Así sea.

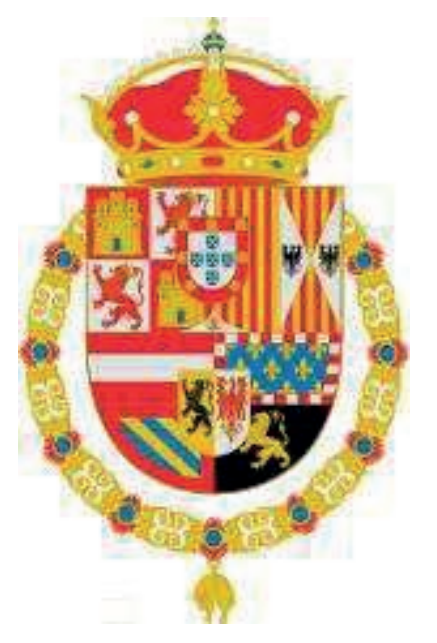

Último escudo con los dos países unidos

(Casa Imperial Habsburgo 1580-1668 --Felipe II, Felipe III y Felipe IV--)

\section{Glosario}

Según el Profesor Español Jordi Serra, todo prospectivista ha de conocer el significado de varios conceptos para poder adentrarse en el mundo de los futuros. Este es: 
Analogía: método por el cual se intenta pronosticar el futuro, bien sobre la base de pasadas experiencias similares, bien observando lo que acontece en otros lugares al mismo tiempo.

Camino retrospectivo (Backcasting): método utilizado en prospectiva. Partiendo de la identificación de un escenario específico, se reconstruye su desarrollo a la inversa, buscando sus orígenes y su evolución. Es el proceso inverso al del pronóstico.

Delphi: método prospectivo desarrollado en la corporación RAND por Palmer y Gordon para obtener datos sobre situaciones futuras. Se basa en cuestionarios a expertos que se repiten en sucesivas iteraciones con vistas a conseguir consenso o refinar la información obtenida.

Escenario: una descripción del futuro, o de uno de sus aspectos, que debe ser internamente coherente, consistente y verosímil. Una de las herramientas más utilizadas en prospectiva y resultado final de muchos métodos.

Extrapolación: práctica que consiste en extender en el futuro una tendencia, situación o proceso al mismo ritmo y en la misma dirección en que se ha desarrollado hasta el presente. Es un método poco usado, ya que supone la proyección del presente en el futuro y la experiencia demuestra que el futuro menos probable es aquél en el que nada cambia.

Futuro proyectivo (Incasting): método de prospectiva desarrollado originariamente por Jim Dator y que consiste en un pronóstico deductivo de futuros alternativos a partir de unas macroimágenes preestablecidas.

Horizonte temporal: plazo con el que se trabaja en cualquier estudio de prospectiva. Generalmente se sitúa a unos quince o veinte años en el futuro. 
Modelo: conjunto de variables que reflejen los componentes más relevantes de un sistema para predecir su comportamiento futuro; incluye una valoración de sus interrelaciones y las normas que rigen su comportamiento. Los modelos se han utilizado mucho en prospectiva, sobre todo en los años sesenta y hasta principios de los setenta, para después caer en desuso. Con los avances en informática y más datos disponibles, vuelven a gozar de aceptación.

Predicción: declaración con total certeza sobre un hecho futuro que sólo puede ser validada o refutada si suceden o no los hechos predichos. A pesar de que suelen confundirse los resultados de cualquier estudio de prospectiva con una predicción, es una idea errónea. En prospectiva se rechaza la noción de predicción pues tiende a reforzar la idea de un futuro único y predeterminado. Se utiliza mejor el concepto de futuros alternativos.

Presente extendido: concepto muy utilizado en prospectiva para combatir la preponderancia del presente como el ahora inaprehensible. Desarrollado sobre todo por Elise Boulding, consiste en extender el presente cien años en el futuro y cien años en el pasado. Para llenarlo de contenido emocional, se presenta como el periodo de vida desde nuestros abuelos hasta nuestros nietos. Intenta evidenciar las conexiones entre el pasado y el futuro.

Pronóstico: declaración probabilística sobre un hecho futuro. Método de predicción que implica la proyección de series de datos para evaluar la ocurrencia probable de un acontecimiento o el desarrollo de una tendencia.

Teoría del caos: cuerpo teórico que combina el estudio de la dinámica de sistemas, la matemática y la física cuántica. Postula que muchos fenómenos son impredecibles. Aporta nuevos conceptos y metáforas para la investigación del cambio dinámico, por 
ejemplo, la bifurcación. Enfatiza el potencial creativo en épocas de cambio turbulento.

Tormenta de ideas (Brainstorming): Método para fomentar la creatividad, utilizado en talleres de futuro. En un entorno donde no se permite la crítica y se anima a pensar de forma inusual, los participantes intentarán tratar los temas de forma creativa.

Utopía: literalmente, fuera del espacio. Forma literaria popular en Europa desde el medioevo en la que el autor describía su sociedad ideal. Posteriormente asociado a objetivos deseables pero difíciles o imposibles de realizar. Hoy, las utopías se consideran imágenes de futuro ligadas a preferencias o deseos, y se diferencian entre eutopías (positivas) y distopías (negativas)

\section{Bibliografía}

BAS, Enric: Prospectiva. Herramienta para la gestión estratégica del cambio. Ed. Ariel Practicum. Barcelona. 1999.

HAMMER M. Y CHAMPY, J.: Reengineering menagement. Ed. Harper Business.

RAIFFA, H.: Decision Analysis (Análisis de decisiones). Addison-Wesley. Nueva York. 1976

VINADER, R.: “¿Qué es la teoría de la decisión?”. Número 33 de Estudios Empresariales. Ed. Universidad de Deusto (Vizcaya). 1976.

\section{Webgrafía y correles de interés}

www.futures.hawaii.edu

www.woldfutures.org

www.wfs.com 
www.europrospective.org

www.ur.mx

www.ucm.es

www.harpercollins.com 